\title{
New records of plant-parasitic nematodes from Iceland
}

\author{
${\text { Łukasz Flis }{ }^{1} \oplus \text {. Franciszek Wojciech Kornobis }{ }^{2} \oplus \cdot \text { Magdalena Kubicz }^{1} \cdot \text { Jón Guðmundsson }}^{3}$
}

Received: 16 December 2019 / Revised: 5 August 2020 / Accepted: 11 August 2020 / Published online: 19 August 2020

(c) The Author(s) 2020

\begin{abstract}
The plant-parasitic nematodes of Iceland are poorly understood. To address this, a study of the nematodes of the families Criconematidae and Hemicycliophoridae was performed in 2015. Soil samples were taken from underneath various host plants in different locations in Iceland. The identification was performed on the basis of the general morphology and subsequently confirmed by molecular markers (D2-D3 28S rDNA). The study revealed the presence of nematode specimens belonging to four species of the family Criconematidae: Criconemoides amorphus, Criconema demani, Mesocriconema xenoplax and Mesocriconema curvatum, as well as one species Hemicycliophora conida of the family Hemicycliophoridae. To our knowledge, this is the first record of the occurrence of these nematode species in Iceland. The species identified are economically important plant-parasitic nematodes of likely interest to-among others-Icelandic plant protection professionals. This report broadens our knowledge of Iceland's nematode biodiversity; moreover, morphological analyses and molecular data may contribute to better understanding the origin of nematode species on the island of Iceland.
\end{abstract}

Keywords New geographic record $\cdot$ C. amorphous $\cdot$ C. demani $\cdot$ M. curvatum $\cdot$ M. xenoplax $\cdot$ H. conida $\cdot$ Iceland

\section{Introduction}

Iceland is a Nordic island country which consists of several small islands and a larger one-the main island of Iceland. It is located in the North Atlantic Ocean at its confluence with the Greenland Sea (part of the Arctic Ocean). Although Iceland forms part of the Arctic region, the country's landscape chiefly reflects its volcanic origins and is significantly human altered, with large unvegetated or sparsely vegetated areas. The vegetated areas account for $44 \%$ of the total area of Iceland. 2.3\% of Iceland's total area is covered by grasslands which largely replaced the natural birch woodland as a result of human activity pursued since the Viking settlement in the ninth century (Aradóttir et al. 2013; Sigurmundsson

Electronic supplementary material The online version of this article (https://doi.org/10.1007/s00300-020-02732-0) contains supplementary material, which is available to authorized users.

Łukasz Flis

1flis@miiz.waw.pl

1 Museum and Institute of Zoology, Polish Academy of Sciences, Wilcza Street, 64, 00-679 Warsaw, Poland

2 Institute of Plant Protection-National Research Institute, Władysława Węgorka Street, 20, 60-318 Poznan, Poland

3 Jakaseli Street, 4, 109 Reykjavík, Iceland et al. 2014). The importance of grasslands for Iceland's farming remains undisputed with permanent grass fields representing the vast majority (around 90\%) of the country's cultivated areas (Helgadóttir et al. 2013). Iceland's wildlife is characterized by a relatively low number of endemic plants and animals (Buckland and Dugmore 1991). Up to date there are 490 species of vascular plants known from this island (Svanberg and Ægisson 2012). Most (if not all) of these species could probably be the food source and form host plants to plant-parasitic nematodes. Currently, there are about 4000 plant-parasitic nematodes known from the world, which is approximately $15 \%$ of known phylum species (Decraemer and Hunt 2013). Many of them are of significant economic importance as major pests of cultivated plants (e.g., Singh et al. 2013). Nevertheless, only several species of plant-parasitic nematodes have been recorded from Iceland so far, as for example Globodera rostochiensis, Meloidogyne arenaria, Anguina radicicola and Ditylenchus dipsaci (Siggeirsson and Riel 1975). One of the economically important plant-parasitic nematode groups are species belonging to the families Criconematidae and Hemicycliophoridae. They inhabit terrestrial soil and are obligatory root-feeding ectoparasites of numerous plant species (Siddiqi 2000; Andrássy 2007). Representatives of Criconematidae are known from all continents (Geraert 2010; Ryss et al. 
2014) and Hemicycliophoridae are found worldwide on all continents except the Antarctic (Andrássy 2007; Subbotin et al. 2014).

To the best of our knowledge, representatives of Hemicycliophoridae have never been recorded from Iceland. As for Criconematidae, the only record of this family comes from the island of Surtsey, which is located off the southern coast of Iceland (Ilieva-Makulec et al. 2015). In this study, however, specimens were identified only down to the family level. Here we present new geographic records on five species of the families Criconematidae and Hemicycliophoridae from Iceland, data on their morphometrics and D2-D3 28S rDNA molecular markers.

\section{Materials and methods}

38 soil samples from the root zones of various host plants were collected in 2015. The samples were obtained from different geographical locations, both in the south and north of Iceland. Nematodes were extracted from the soil by the centrifugal flotation method (Van Bezooijen 2006) and observed alive under the dissecting microscope. Out of each sample 1-5 Criconemoides amorphus, Criconema demani, Mesocriconema curvatum, Mesocriconema xenoplax and Hemicycliophora conida specimens were preserved in DESS for the purposes of molecular studies (Yoder et al. 2006). Remaining specimens were gently heat killed and preserved in TAF solution and submitted for morphological analysis (Courtney et al. 1955). From TAF, nematodes were transferred to glycerine (Seinhorst 1959) and subsequently mounted on microscopic slides. Morphological observations, measurements and photographs were obtained using a Leica light microscope with the Nomarski differential interference contrast. Single nematode individuals from DESS, after washing in sterilized milli-Q water, were used for DNA extraction. DNA was isolated from specimens according to the nematode lysis procedure, as described by Holterman et al. (2006). The obtained single nematode lysate (crude DNA extract) was used immediately as a DNA template for a PCR reaction or stored at $-20{ }^{\circ} \mathrm{C}$. PCR reactions were performed in Veriti 96-Well Thermal Cycler (Applied Biosystems, Foster City, CA, USA). Both PCR and sequencing were performed using the D2A and D3B primers (Nunn 1992). Amplicons were visualized under UV illumination after Simply Safe (EURx, Gdańsk, Poland) gel staining and gel electrophoresis. The $28 \mathrm{~S}$ rDNA regions were sequenced by the Sanger method on ABI 3500L genetic analyser (Applied Biosystems, Foster City, CA, USA). The quality of obtained chromatograms was assessed in Chromas Lite 2.1.1 (http://www.technelysium.com.au). Final sequences were determined by assembling sequences obtained from opposite directions in BioEdit (Hall 1999) and deposited in GenBank.

\section{Results and discussion}

Overall, in our study, species of Criconematidae and Hemicycliophoridae families have been found only in samples from the region of South Iceland. The geographic coordinates of sampling locations are presented in Table 1. Outline maps indicating the regional setting of our study on the island of Iceland, and more broadly, in the Arctic, are given in Online Resource 1. Seven samples were found to carry nematodes of Criconematidae family, whereas in one sample nematodes of Hemicycliophoridae family were found (Table 1). Analyses of the investigated females confirmed their affiliation to four species of the family Criconematidae: Criconema demani Micoletzky 1925, Criconemoides

Table 1 Plant-parasitic nematode species found on plants in Iceland with habitat location coordinates

\begin{tabular}{|c|c|c|c|}
\hline Nematode species & Plant species & $\begin{array}{l}\text { Sample } \\
\text { reference } \\
\text { number }\end{array}$ & $\begin{array}{l}\text { Approximate geographical coordinates/height above } \\
\text { sea level }\end{array}$ \\
\hline Criconema demani & Vicia cracca $\mathrm{L}$. & I & $63^{\circ} 50^{\prime} 00^{\prime \prime} \mathrm{N}, 20^{\circ} 07^{\prime} 03^{\prime \prime} \mathrm{W} / 96 \mathrm{~m}$ a.s.l (all populations \\
\hline \multirow[t]{3}{*}{ Criconemoides amorphous (three populations) } & Lathyrus japonicus Wild. & II & were in close proximity to one another) \\
\hline & Lotus corniculatus $\mathrm{L}$. & III & \\
\hline & Vicia cracca $\mathrm{L}$. & I & \\
\hline Mesocriconema curvatum & Lotus corniculatus $\mathrm{L}$. & III & \\
\hline \multirow[t]{4}{*}{ Mesocriconema xenoplax (five populations) } & Trifolium pratense $\mathrm{L}$. & IV & \\
\hline & Vicia cracca $\mathrm{L}$. & I & \\
\hline & Vicia sepium $\mathrm{L}$. & $\mathrm{V}$ & \\
\hline & $\begin{array}{l}\text { two populations on } \\
\text { Leymus arenarius (L.) } \\
\text { Hochst }\end{array}$ & VI, VII & $63^{\circ} 32^{\prime} 38^{\prime \prime} \mathrm{N}, 20^{\circ} 06^{\prime} 27^{\prime \prime} \mathrm{W} / 4 \mathrm{~m}$ a.s.1 \\
\hline Hemicycliophora conida & Vicia sepium $\mathrm{L}$. & VIII & $63^{\circ} 47^{\prime} 18^{\prime \prime} \mathrm{N}, 20^{\circ} 17^{\prime} 02^{\prime \prime} \mathrm{W} / 20 \mathrm{~m}$ a.s.1 \\
\hline
\end{tabular}


amorphous De Grisse 1967, Mesocriconema xenoplax (Raski 1952) Loof \& De Grisse 1989, Mesocriconema curvatum (Raski 1952) Loof \& De Grisse 1989 and one species Hemicycliophora conida Thorne 1955 of the family Hemicycliophoridae. Morphological observations of all identified species were in line with descriptions published by other authors (Brzeski 1998; Geraert 2010; Subbotin et al. 2014). Data on morphometrics of specimens of each species are presented in Online Resource 2. Molecular characteristics using LSU (28S rDNA) were also provided. Obtained sequences D2-D3 28S rDNA of each species were deposited in GenBank under the following accession numbers: $C$. demani: MN628432, H. conida: MN628433, M. xenoplax: MN628435, C. amorphus: MN628431 and M. curvatum: MN628434. BLAST search of obtained 28S rDNA GenBank revealed the following results: sequences of C. demani showed a $98 \%$ similarity to the sequences of $C$. demani number MH828126 and MH828128; M. xenoplax a 98-99\% similarity with 24 sequences of $M$. xenoplax published by different authors, for example with sequence DQ077792 (De Ley et al. 2005) and AY780963 (Subbotin et al. 2005); $M$. curvatum showed $99.7 \%$ similarity to the $M$. curvatum MN720094 (Mwamula et al. 2020); H. conida a 99\% similarity to the sequences of $H$. conida numbers FN433875 (unpublished), KF430448 and KF430447 (Subbotin et al. 2014). Finally, BLAST search of sequences from C. amorphus revealed similarity to other sequences from criconematids, however, not an important one.

The identification of five plant-parasitic nematode species, from the region of South Iceland, largely expands the list of species known from this island country. Species of the family Criconematidae were found on the following plants: Vicia cracca L., Vicia sepium L., Lathyrus japonicus Wild., Leymus arenarius (L.) Hochst., Lotus corniculatus L., Trifolium pratense $\mathrm{L}$. and the family Hemicycliophoridae, a population of the single species, was found in the rhizosphere of $V$. sepium L. (Table 1). Additionally, at least some of the investigated species are of known economic importance as plant pests and could potentially cause crop yield losses in Iceland's farming sector. Below we present a short outline of each species' biology, its known geographic range and economic impact.

Criconema demani (Fig. 1a-c) was reported from many countries in Europe, including the European part of Russia (Bongers 1988; Escuer and Bello 1994; Brzeski 1998; Bert et al. 2003; Tabolin 2017), also from Korea (Choi and Geraert 1975), as well North (Bernard 1980; Luna-Guerrero et al. 2011) and South America (Crozzoli and Lamberti 2002). It is found mainly in agricultural crops (Bernard 1980; Crozzoli 2002). This species has been found to be co-responsible for the development of Peach Tree Short Life (PTSL) disease (Luna-Guerrero et al. 2011). With regards to Iceland, we found this species in patches of uncultivated land, i.e., in one soil sample of the basalt sand on a lava flow originating in the nearby Mount Hekla volcano, later referred to as "Hekla".

Criconemoides amorphus (Fig. 1d-f) was first described from Belgium (Luc 1970). This species is known to occur also in the Netherlands (Bongers 1988), Spain (Castillo and Gómez-Barcina 1993), Italy (Bello et al. 1988), Russia (Tabolin 2017) and Iraq (Stephan et al. 1985). It is found in intact as well agricultural habitats (Antoniou 1981; Bello et al. 1988; Budurova et al. 1996; Mateille et al. 2011; Renco and Baležentiené 2015) and is considered a major grapevine pest (Antoniou 1981; Stephan et al. 1985; Escuer and Bello 1994; Philis 1995). In wastelands it was found to occur on herbaceous and dune plants (Escuer and Bello 1996; Talavera and Navas 2002; Mateille et al. 2011). Criconemoides amorphus reported from Iceland occurred in two soil samples collected from a non-agricultural vegetated habitat, under a leguminous plant community, in the basalt sand on lava flow from Hekla.

Mesocriconema xenoplax (Fig. 1g-i) is a polyphagous cosmopolitan species (Wouts 2006). There are reports of its occurrence both in farmed land and in areas not in agricultural use, on a wide range of plants (Zehr et al. 1986; Winiszewska et al. 2012, 2017; Powers et al. 2014). The species is commonly found in vineyards worldwide where it has been observed to develop more rapidly and cause greater damage to vine than other species of the genus Mesocriconema (Walker 1995; McKenry and Anwar 2006; Wiśniewska et al. 2013; Skwiercz et al. 2015). It is a major factor in PTSL syndrome in the United States and other parts of the world (Gomes et al. 2000; Walters et al. 2008). In our study this species was found to be the most common as it occurred in five soil samples. Its presence was found on various plants in the basalt sand on lava from Hekla and in dunes located about 300-1000 m from Iceland's southern coast.

Mesocriconema curvatum has a broad geographic distribution (Wouts 2006), covering almost all continents with reports of its occurrence from the United States (Zeng et al. 2012), Europe (Castillo and Gómez-Barcina 1993; Winiszewska et al. 2012, 2017), Asia (Choi and Geraert 1975; Mwamula et al. 2020) and Africa (Lamberti et al. 1991; De Waele et al. 1998). In general this species has agricultural associations; however, it was also found in uncultivated grasslands (Powers et al. 2014). We found only two specimens in the basalt sand on a lava flow from Hekla.

Hemicycliophora conida (Fig. 1j-1) was first described from Ireland by Thorne (1955). The species has been widely reported from European countries (Loof 1968; Brzeski 1998; Peña-Santiago et al. 2004), Iran (Loof 1984), the Americas (Subbotin et al. 2014), South Africa (Van den Berg 1981) and Svalbard, high Arctic tundra (Kerfahi et al. 2017). As an obligate ectoparasite of plants, it inhibits growth and contorts the shape of root systems in farm crops (Winiszewska 

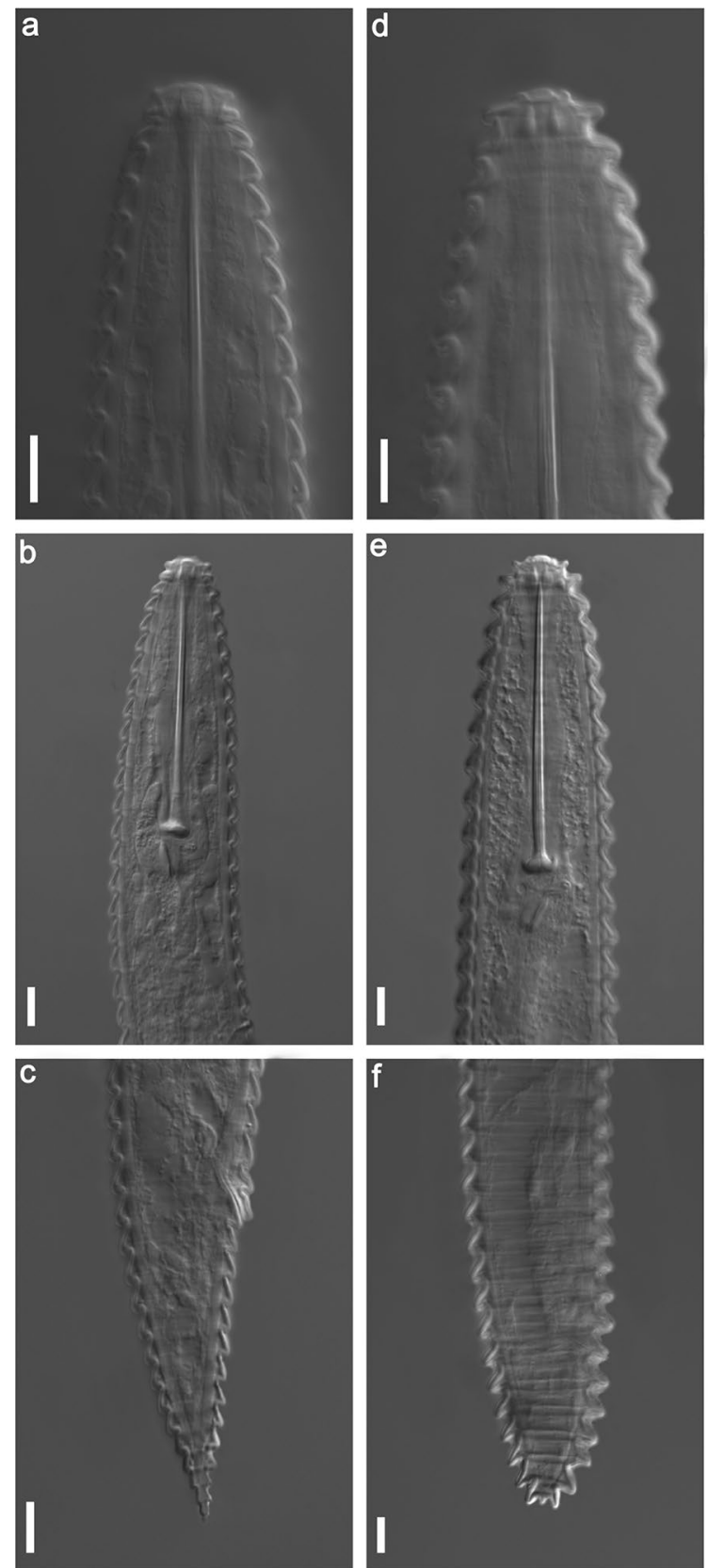

Fig. 1 Criconema demani Micoletzky 1925, female. a Shape of head; $\mathbf{b}$ anterior body region; $\mathbf{c}$ posterior body region. Criconemoides amorphus De Grisse 1967, female. d Shape of head; e anterior body region; f posterior body region. Mesocriconema xenoplax (Raski

et al. 2012; Chitambar and Subbotin 2014; Van Den Berg et al. 2018). This species has been found to occur in Iceland in one location only in the basalt sand from the bank of the river Eystri-Rangá.

The study broadens our knowledge of the distribution of the species $C$. amorphus, $C$. demani, M. xenoplax, $M$. curvatum and $H$. conida. Aside from the potential threat to agriculture, the occurrence of plant-parasitic nematodes in
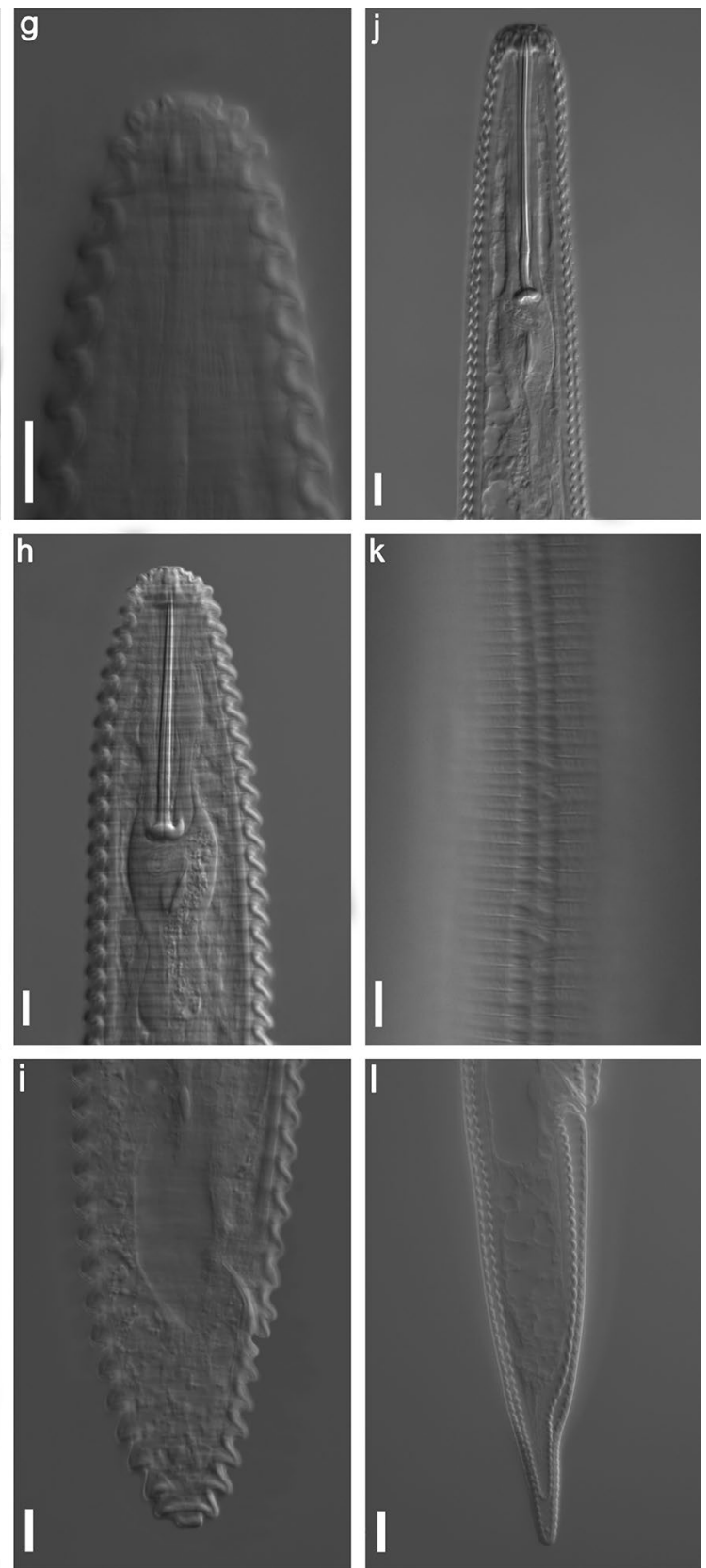

1952) Loof \& De Grisse 1989, female. g Shape of head; h anterior body region; i posterior body region. Hemicycliophora conida Thorne 1955, female. j Anterior body region; k lateral field; l posterior body region. Scale bars $=10 \mu \mathrm{m}$

Iceland can become an interesting field of biogeographic research. For example it is not clear how the plant-parasitic nematodes survived the Pleistocene glaciations. Currently, there are two major concepts of species origin on the island of Iceland. The first one, "tabula rasa", indicates that all species on the island arrived there after the end of the glaciation period. The second one, "glacial refugia", assumes that species were able to survive the glacial period on the 
island within refugias. In case of plant-parasitic nematodes, the survival of their hosts, the vascular plants, is probable (Rundgren and Ingólfsson 1999). That could enable the survival of the nematodes. It does not necessarily follow, however, that all plant-parasitic nematodes occurring in Iceland have survived the glaciation in refugias. Some nematode species might have been transferred to Iceland after the glaciation by either natural causes or human activity. To establish how those species arrived in Iceland, further studies will be necessary involving a larger number of Icelandic populations and their comparison with populations from mainland Europe and North America.

\section{Conclusion}

This report broadens our knowledge of nematode biodiversity of Iceland as well of the morphometry and molecular characteristics of the five economically important species C. amorphus, C. demani, M. xenoplax, $M$. curvatum and $H$. conida. The study yielded molecular data which may contribute to the further development of the concepts of species origin of nematodes on the island of Iceland. Our observations could draw the attention of, among others, Icelandic agricultural practitioners and plant protection experts to the interaction between the cropping system and the populations of nematodes newly investigated in Iceland. To our knowledge this is the first report of five species of the families Criconematidae and Hemicycliophoridae from Iceland.

Acknowledgements This work was supported by the Museum and Institute of Zoology PAS. The authors would like to thank the reviewers Etienne Geraert and Andrij Susulovsky for their valuable comments and remarks. We also thank Marcin Wardal for his collaboration.

\section{Compliance with ethical standards}

Conflict of interest The authors declare that they have no conflict of interest.

Open Access This article is licensed under a Creative Commons Attribution 4.0 International License, which permits use, sharing, adaptation, distribution and reproduction in any medium or format, as long as you give appropriate credit to the original author(s) and the source, provide a link to the Creative Commons licence, and indicate if changes were made. The images or other third party material in this article are included in the article's Creative Commons licence, unless indicated otherwise in a credit line to the material. If material is not included in the article's Creative Commons licence and your intended use is not permitted by statutory regulation or exceeds the permitted use, you will need to obtain permission directly from the copyright holder. To view a copy of this licence, visit http://creativecommons.org/licenses/by/4.0/.

\section{References}

Andrássy I (2007) Free-living nematodes of Hungary, II (Nematoda errantia). Hungarian Natural History Museum and Systematic Zoology Research, Group of the Hungarian Academy of Sciences, Budapest, pp 282-333

Antoniou M (1981) A nematological survey of vineyards in Cyprus. Nematol Mediterr 9:133-137

Aradóttir ÁL, Petursdottir T, Halldorsson G et al (2013) Drivers of ecological restoration: lessons from a century of restoration in Iceland. Ecol Soc 18:33. https://doi.org/10.5751/ES-05946-180433

Bello A, Coiro MI, Rey JM (1988) Criconematoidea sensu Siddiqi, 1980 en los vifiedos del Trentino. Nematol Mediterr 16:25-33

Bernard EC (1980) Identification, distribution, and plant associations of plant-parasitic nematodes in Tennessee. Univ Tenn Agric Exp Stn Bull 594:1-20

Bert W, Coomans A, Claerbout F, Geraert E, Borgonie G (2003) Tylenchomorpha (Nematoda: Tylenchina) in Belgium, an updated list. Nematology 5:435-440

Bongers T (1988) De nematoden van Nederland. Koninklijke Natuurhistorische Vereniging, Utrecht, p 408

Brzeski MW (1998) Nematodes of Tylenchina in Poland and temperate Europe. Museum and Institute of Zoology Polish Academy of Sciences, Warsaw, p 294

Buckland P, Dugmore A (1991) 'If this is a refugium, why are my feet so bloody cold?' The origins of the Icelandic biota in the light of recent research. In: Maizels JK, Caseldine C (eds) Environmental change in Iceland: past and present. Kluwer Academic Publishers, Dordrecht, pp 107-125. https://doi. org/10.1007/978-94-011-3150-6_8

Budurova L, Baicheva O, Milkova M (1996) Formation of the wheat nematode fauna under monoculture conditions in the region of Razgrad. Biotechnol Biotechnol Equip 10:34-37. https://doi. org/10.1080/13102818.1996.10818894

Castillo P, Gómez-Barcina A (1993) Plant-parasitic nematodes associated with tropical and subtropical crops in southern Spain. Nematol Mediterr 21:45-47

Chitambar JJ, Subbotin SA (2014) Systematics of the sheath nematodes of the superfamily Hemicycliophoroidea. In: Hunt DJ, Perry RN (eds) Nematology monographs and perspectives. Brill, Leiden, p 732

Choi YE, Geraert E (1975) Criconematids from Korea with the description of eight new species (Nematoda: Tylenchida). Nematologica 21:35-52

Courtney WD, Polley D, Miller VL (1955) TAF, an improved fixative in nematode technique. Plant Dis Rep 39:570-571

Crozzoli R (2002) Especies de nematodos fitoparasíticos en Venezuela. Interciencia 27:354-364

Crozzoli R, Lamberti F (2002) Species of Criconema Hofmanner and Menzel, 1914 and Ogma Southern, 1914 occurring in Venezuela, with description of Ogma araguanensis sp. n. (Nematoda: Criconematidae). Russ J Nematol 10:89-98

De Grisse A (1967) Description of fourteen new species of Criconematidae with remarks on different species of this family. Biologisch Jaarboek Dodonaea 35:66-125

De Ley P, De Ley IT, Morris K et al (2005) An integrated approach to fast and informative morphological vouchering of nematodes for applications in molecular barcoding. Philos Trans R Soc B 360:1945-1958. https://doi.org/10.1098/rstb.2005.1726

De Waele D, McDonald AH, Jordaan EM, Orion D, Van den Berg E, Loots GC (1998) Plant-parasitic nematodes associated with maize and pearl millet in Namibia. Afr Plant Prot 2:113-117

Decraemer W, Hunt DJ (2013) Structure and classification. In: Perry RN, Moens M (eds) Plant nematology, 2nd edn. CABI Publishing, Wallingford, pp 3-39 
Escuer M, Bello A (1994) Nematodos del suelo de la familia Criconematidae en Cataluña. Orsis 9:59-75

Escuer M, Bello A (1996) Nematodos de la subfamilia Macroposthoniinae (Nematoda: Criconematidae) en la España peninsular. Orsis 1:59-92

Geraert E (2010) The Criconematidae of the world-identification of the family Criconematidae (Nematoda). Academia Press, Ghent

Gomes CB, Campos AD, Almeida MRA (2000) Occurrence of Mesocriconema xenoplax and Meloidogyne javanica associated with peach tree short life on plum and reduction of phenol oxidizing enzyme activity. Nematol Bras 24:249-252

Hall TA (1999) BioEdit: a user-friendly biological sequence alignment editor and analysis program for Windows 95/98/NT. Nucleic Acids Symp 41:95-98

Helgadóttir Á, Eythórsdóttir E, Jóhannesson T (2013) Agriculture in Iceland-a grassland based production. In: Helgadóttir Á, Hopkins A (eds) The role of grasslands in a green future. Threats and perspectives in less favoured areas. Proceedings of the 17th Symposium of the European Grassland Federation, Akureyri, Iceland, 23-26 June 2013, Agricultural University of Iceland, Grassland Science in Europe 18, pp 30-43

Holterman M, Van Der Wurff A, Van Den Elsen S et al (2006) Phylum-wide analysis of SSU rDNA reveals deep phylogenetic relationships among nematodes and accelerated evolution toward crown clades. Mol Biol Evol 23:1792-1800. https://doi. org/10.1093/molbev/ms1044

Ilieva-Makulec K, Bjarnadottir B, Sigurdsson BD (2015) Soil nematode communities on Surtsey, 50 years after the formation of the volcanic island. Icel Agric Sci 28:43-58. https://doi. org/10.16886/IAS.2015.05

Kerfahi D, Park J, Tripathi BM et al (2017) Molecular methods reveal controls on nematode community structure and unexpectedly high nematode diversity, in Svalbard high Arctic tundra. Polar Biol 40:765-776. https://doi.org/10.1007/s0030 0-016-1999-6

Lamberti F, Ciancio A, Tuopay DK et al (1991) Nematode threats to rice in Liberia. Nematol Mediterr 19:291-303

Loof PAA (1968) Taxonomy of Hemicycliophora species from west and central Europe (Nematoda: Criconematoidea). Meded Landbouwhogeschool Wageningen 68:1-43

Loof PAA (1984) Hemicycliophora species from Iran (Nematoda: Criconematoidea). Nematologica 30:22-41

Loof PAA, De Grisse A (1989) Taxonomic and nomenclatorial observations on genus Criconemella De Grisse and Loof, 1965 sensu Luc and Raski, 1981. Meded Fac Landbouwwet, Rijksuniv Gent 54:53-74

Luc M (1970) Contribution a l'etude du genre Criconemoides Taylor, 1936 (Nematoda: Criconematidae). Cahiers Orstom, Serie Biologie 11:69-131

Luna-Guerrero AY, Montes-Belmont R, Talavera-Rubia MF et al (2011) Estudio preliminar de los factores bióticos y abióticos asociados a la muerte del duraznero en Morelos, México. Nematropica 41:254-262

Mateille T, Tavoillot J, Martiny B et al (2011) Plant-associated nematode communities in West-palearctic coastal foredunes may relate to climate and sediment origins. Appl Soil Ecol 49:81-93. https:// doi.org/10.1016/j.apsoil.2011.06.012

McKenry MV, Anwar SA (2006) Nematode and grape rootstock interactions including an improved understanding of tolerance. J Nematol 38:312-318

Micoletzky H (1925) Die freilebenden Süsswasser- und Moornematoden Dänemarks. Det Kongelige Danske Videnskabelige Seldskap Skrifter, Naturvidenskabelige og Mathematiske Afdeling 8:57-310

Mwamula AO, Kabir MF, Lee G et al (2020) Morphological characterisation and molecular phylogeny of several species of
Criconematina (Nematoda: Tylenchida) associated with turfgrass in Korea, as inferred from ribosomal and mitochondrial DNA. Nematology. https://doi.org/10.1163/15685411-bja10003

Nunn GB (1992) Nematode molecular evolution. An investigation of evolutionary patterns among nematodes based upon DNA sequences. Ph. D. dissertation. University of Nottingham, UK, pp 187

Peña-Santiago R, Castillo P, Escuer M et al (2004) Tylenchid species (Nematoda, Tylenchida) recorded in the Iberian Peninsula and the Balearic Islands: a compendium. Collection 'Monographic Papers on Nematology' no 2. Editorial Universidad de Jaén, pp 127

Philis J (1995) An up-dated list of plant-parasitic nematodes from Cyprus and their economic importance. Nematol Mediterr 23:307-314

Powers TO, Bernard EC, Harris T et al (2014) COI haplotype groups in Mesocriconema (Nematoda: Criconematidae) and their morphospecies associations. Zootaxa 3827:101-146. https://doi. org/10.11646/zootaxa.3827.2.1

Raski DJ (1952) On the morphology of Criconemoides Taylor, 1936, with descriptions of six new species (Nematoda: Criconematidae). Proc Helminthol Soc Wash 19:85-99

Renco M, Baležentiené L (2015) An analysis of soil free-living and plant-parasitic nematode communities in three habitats invaded by Heracleum sosnowskyi in central Lithuania. Biol Invasions 17:1025-1039. https://doi.org/10.1007/s10530-014-0773-3

Rundgren M, Ingólfsson O (1999) Plant survival in Iceland during periods of glaciation? J Biogeogr 26:387-396

Ryss A, Andreev M, Kurbatowa L (2014) Nematodes of the land ecosystems of Antarctica. Conference Paper, Ekoperspektiva, Minsk, pp 221-224

Seinhorst JW (1959) A rapid method for the transfer of nematodes from fixative to anhydrous glycerine. Nematologica 4:67-69. https://doi.org/10.1163/187529259X00381

Siddiqi MR (2000) Tylenchida: parasites of plants and insects, 2nd edn. CABI Publishing, Wallingford, p 833

Siggeirsson EI, Riel HR (1975) Plant-parasitic nematodes in Iceland. Sníkjuprádomar í plöntum á Íslandi. Rannsóknastofnunin Nedri Ás, Hveragerdi, Ísland Skýrsla. no. 20, pp 32

Sigurmundsson FS, Gísladóttir G, Óskarsson H (2014) Decline of birch woodland cover in Pjórsárdalur Iceland from 1587 to 1938. Hum Ecol 42:577-590. https://doi.org/10.1007/s1074 5-014-9670-8

Singh SK, Hodda M, Ash GJ (2013) Plant-parasitic nematodes of potential phytosanitary importance, their main hosts and reported yield losses. OEPP/EPPO Bull 43:334-374. https:// doi.org/10.1111/epp.12050

Skwiercz AT, Dzięgielewska M, Szelągowska P (2015) Nematodes in the vineyards in the northwestern part of Poland. Acta Sci Pol Hortoru 14:3-12

Stephan ZA, Alwan AH, Antone BG (1985) Occurrence of plantparasitic nematodes in vineyard soils in Iraq. Nematol Mediterr 13:261-264

Subbotin SA, Chitambar JJ, Chizhov VN et al (2014) Molecular phylogeny, diagnostics, and diversity of plant-parasitic nematodes of the genus Hemicycliophora (Nematoda: Hemicycliophoridae). Zool J Linn Soc Lond 171:475-506. https://doi. org/10.1111/zoj.12145

Subbotin SA, Vovlas N, Crozzoli R et al (2005) Phylogeny of Criconematina Siddiqi, 1980 (Nematoda: Tylenchida) based on morphology and D2-D3 expansion segments of the 28S-rRNA gene sequences with application of a secondary structure model. Nematology 7:927-944. https://doi.org/10.1163/1568541057 76186307

Svanberg I, Ægisson S (2012) Edible wild plant use in the Faroe Islands and Iceland. Acta Soc Bot Pol 81:233-238. https://doi. org/10.5586/asbp.2012.035 
Tabolin SB (2017) On the faunistic diversity of nematodes of the family Criconematidae in the European part of Russia. In: Zryanin VA, Ryss AY (ed) Abstracts of the 12th International Symposium of the Russian Society of Nematologists "Nematodes and other Ecdysozoa under the growing ecological footprint on ecosystems", Nizhny Novgorod, Russia, 31 July-6 August, 2017, Lobachevsky State University of Nizhni Novgorod, pp 118-119

Talavera M, Navas A (2002) Incidence of plant-parasitic nematodes in natural and semi-natural mountain grassland and the host status of some common grass species. Nematology 4:541-552

Thorne G (1955) Fifteen new species of the genus Hemicycliophora with an emended description of $H$. typica de Man (Tylenchida: Criconematidae). Proc Helminthol Soc Wash 22:1-16

Van Bezooijen J (2006) Methods and techniques for nematology. Revised version 2006. Wageningen University, Wageningen, pp 46-50

Van Den Berg E (1981) Further studies on the genus Hemicycliophora de Man, 1921 in South Africa (Nematoda: Hemicycliophoroidea) with a description of a new species. Phytophylactica 13:181-194

Van Den Berg E, Tiedt LR, Liébanas G et al (2018) Morphological and molecular characterisation of two new Hemicycliophora species (Tylenchida: Hemicycliophoridae) with a revision of the taxonomic status of some known species and a phylogeny of the genus. Nematology 20:319-354. https://doi.org/10.1163/15685 411-00003143

Walker G (1995) Nematode associated with grapevine foundation plantings at Loxton. Aust NZ Grapegrow Winemak 381:34-40

Walters SA, Bond JP, Russell JB, Taylor BH, Handoo ZA (2008) Incidence and influence of plant-parasitic nematodes in southern Illinois peach orchards. Nematropica 38:63-74
Winiszewska G, Dmowska E, Chałańska A et al (2012) Nematodes associated with plant growth inhibition in the Wielkopolska region. J Plant Prot Res 52:440-446. https://doi.org/10.2478/ v10045-012-0071-y

Winiszewska G, Dmowska E, Flis Ł, Wiśniewska O (2017) Contribution to the knowledge of plant-parasitic nematodes (Nematoda: Tylenchida) of Ojców National Park. Prądnik Prace Muz Szafera 27:89-92

Wiśniewska O, Gralak O, Flis Ł, Kornobis F (2013) Occurrence of plant-parasitic nematodes in vineyards of southern Poland. Prog Plant Prot 53:809-813

Wouts WM (2006) Criconematina (Nematoda: Tylenchida). Fauna N Z 55:1-228

Yoder M, De Ley IT, King IW et al (2006) DESS: a versatile solution for preserving morphology and extractable DNA of nematodes. Nematology 8:367-376. https://doi.org/10.1163/1568541067 78493448

Zehr EI, Lewis SA, Bonner MJ (1986) Some herbaceous hosts of the ring nematode (Criconemella xenoplax). Plant Dis 79:1066-1069. https://doi.org/10.1094/PD-70-1066

Zeng Y, Weimin YE, Tredway L, Martin S, Martin M (2012) Taxonomy and morphology of plant-parasitic nematodes associated with turfgrasses in North and South Carolina, USA. Zootaxa 3452:1-46. https://doi.org/10.11646/zootaxa.3452.1.1

Publisher's Note Springer Nature remains neutral with regard to jurisdictional claims in published maps and institutional affiliations. 